\title{
НОВЫЕ ВЫЗОВЫ
}

И УГРОЗЫ БЕЗОПАСНОСТИ

СОВРЕМЕННЫХ ГОСУААРСТВ

\author{
Иванов С. М.
}

\section{РОАЬ И ЗНАЧЕНИЕ ИРАКСКОГО КУРАИСТАНА В РЕГИОНААЬНОЙ ГЕОПОАИТИКЕ}

\begin{abstract}
Аннотация. Настоящал статья посвящена исследованию роли и места Иракского Курдистана в мировой и региональной политике. Иракский Курдистан представляет собой уникальную модель справедливого решения курдской проблемы в рамках одной страны, гибкого сочетания двух основных приниипов международного права: права наций на самоопределение и территориальной иелостности государств. В курдском регионе сложилась довольно стройная демократическая система власти, созданы основные институты гражданского общества, независимые СМИ, зарегистрированы десятки политических партий и сотни общественных организачий. Вместе стем, исламисты из организации «Исламское государство Ирака и Аеванта» настроены демонтировать курдскую автономию в составе Ирака, превратив ее в территорию радикальной суннитской диктатуры. Методология исследования включает в себя системный, структурно-функциональный исравнительно-политический подходы, методы индукиии, дедукиии, анализа, синтеза инаблюдения. В складывающихся условиях России желательно сохранить и, по возможности, растирить свое присутствие в Иракском Курдистане. От уровня и наполненности конкретными проектами российско-курдских отночений будут во многом зависеть и перспективы дальнейшего взаимодействия РФ с Ираком, Сирией, Ираном и Туриией. Эрбиль уже давно превратился в самостоятельного игрока в региональной и международной политике и этот фактор следует учитывать российским внешнеполитическим и внешнеэкономическим ведомствам. Похоже на то, ито период сдержанности российского руководства по отночению к Иракскому Курдистану и выстраивания отношений с Эрбилем «с оглядкой» на Багдад подходит к кониу. Переломным событием стала встреча Президента РФ В.В. Путина с президентом Иркского Курдистана Масудом Барзани в феврале 2013 года и создание на территории Ирака и Сирии Исламского халифата.

Ключевые слова: Конфликтология, внешняя политика, Иракский Курдистан, Барзани, Ирак, региональная политика, геополитика, ИГИА, конфликт, безопасность.
\end{abstract}


И

скусственный раздел Османской империи странами-победитемями в Первой мировой войны (Великобританией и Францией) не позволил курАскомународу создать свое государство. Многомимлионный курАский этнос оказался в положении национальных меньшинств в четырех странах БАижнего и Среднего Востока (Турции, Ирана, Ирака и Сирии). Политика центральных властей по отношению к курАам быма схожей во всех перечисленных выше странах: Аискриминация по национальному признаку, насимьственная ассимимяция, переселение, репрессии, вплоть Ао актов геноциАа и применения против мирного насемения химического оружия во времена правления Садаама Хусейна. Курдские восстания вспыхива и повсеместно и жестоко

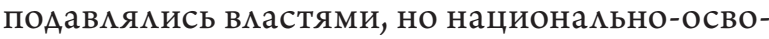
бодительное Авижение курАов За свои права и свободы продолжалось и с кажАым годом набирало симу. К началу XXI века БагдаА, Анкара, Тегеран, Аамаск вынужАены были признать существование курАского этноса и пойти ему на некоторые уступки.

В условиях затяжной гражАанской войны в Сирии правительственные войска оставили районы компактного проживания сирийских курдов и предоставили им возможность созАать органы самоуправления и отряды самообороны, властям Турции уданось добиться прекращения партизанской войны Рабочей партии Курдистана (РПК) и перевести Аиалог с курАами в мирное русло. Снизилась активность курАскихповстанцев в Иранском КурАистане, поскольку новый президент ИРИ Х. Роухани пообещал удемять больше внимания социально-экономическому развитию наиболее отстамых кураских районов. И все же наибольших успехов в своем самоопределении Аобились иракские кураы.

Иракский КурАистан преАставмяет собой уникальную модель справеАливого решения курАской проблемы в рамках оАной страны, гибкого сочетания Авух основных принципов межАународного права: права наций на самоопределение и территориальной целостности государств. За прошедшие 11 мет после свержения режима СаААама Хусейна Курдистанскому автономному району Ирака (три северные провинции страны: Эрбимь, Аохук, Сумеймания)
УАалось пройти сложный путь законодательного закрепления завоеванных ранее с оружием в руках прав и свобод в новой иракской конституции и добиться статуса субъекта феАерации с самыми широкими правами. Иракский КурАистан сегодня обладает всеми атрибутами государства: фАаг, гимн, конституция, региональный своА законов, парламент, президент, правительство, судебная и налоговая системы, правоохранительные, пограничные и таможенные органы, вкцючая регионацьные вооруженные симы (бригады «пешмерга»), региональное правительство осуществляет внешнеполитическую и внешнеэкономическую Аеятельность.

В курАском регионе сложилась Аовольно стройная демократическая система вАасти, созданы основные институты гражданского общества, независимые СМИ, зарегистрированы десятки политических партий и сотни общественных организаций - в кучших траАициях формирования автономного смоуправмения ${ }^{1}$. Правящей партией остается Аемократическая партия Курдистана (АПК) во гмаве со своим бессменным мидером Масудом Барзани. СозАана эта партия в 1946 году Мустафой Барзани. ОАнако конкуренцию ей составАяют отколовшийся от АПКв 1975 году Патриотический союз КурАистана (ПСК) во главе с Ажамялем Талабани и вышеАшее из ПСК в 2009 году «Авижение за перемены» (Горан) мидер Наширван Мустафа. Горан выступает за Аальнейшую миберализацию власти, отказ от традиционных трайбалистских подходов при формировании правительства и силовых структур, снижение уровня коррупции и т.п. На последних региональных парламентских выборах «Авижение за перемены» оттеснимо ПСК на третье место, преАставители Горан быми избраны и в федеральный парламент. В политической жизни страны и региона активно участвуют и преАставители «Исламского союза Курдистана», «Исламского Авижения КурАистана», Аругих исламских, христианских

\footnotetext{
${ }^{1}$ Филиппов В. Р. Национально-культурная автономия: классическая концепция и ее современная интерпретация. / / В сборнике: Национально-культурная автономия: проблемы и сужАения. РеА. Филиппова Е.И. Сер. «ЭтноАиамоги» Москва, 1998. С. 63-84.
} 
и туркменских партий. В законодательных и исполнительных органах власти Иракского КурАистана широко преАставлены женщины, практически все национамьные и религиозные меньшинства (курды-езиды, армяне, арабы, христиане, туркоманы, ассирийцы и Аругие). Секулярность, толерантность ко всем группам населения, благожелатемьное отношение к иностранцам весьма характерны Аля КурАистанского региона Ирака.

В регионе аккредитовано свыше 30 иностранныхАипломатическихпреАставительств, вкцючая Генерацьное консумьство РФ, Аесятки иностранных торговых миссий, работают тысячи национамьных, иностранных и со смешанным капиталом фирм и компаний. Министерством торговми и промышиенности Иракского КурАистана зарегистрировано свыше 2300 межАународных иностранных компаний в Аополнение к 15000 иракских компаний, успешно работающих в регионе.

КурАистан переживает строительный бум: возводятся новые электростанции, ирригационные сооружения, мосты, Аороги, аэропорты, жимые кварталы, гостиницы, туристические компиексы, университеты, институты, среАние специамьные учебные заведения, школы, больницы, восстанавливаются разрушенные войной промыш енность, семьское хозяйство, населенные пункты. На фоне Аругих регионов Ирака зАесь относительно безопасно с точки зрения уровня террористической активности боевиков-исламистов, налаживаются взаимовыгодные АобрососеАские отношения с Турцией, Ираном, Аругими странами. Регион занимает подчеркнуто нейтрахьную позицию по отношению к событиям в Сирии и суннитско-шиитскому вооруженному противостоянию арабов в Ираке.

Поступатемьному экономическому росту региона способствует факт отмены введенных ранее ООН межАународных ограничительных санкций в отношении Ирака, стабильность внутриполитической и военно-политической обстановки в регионе, выгодное географическое расположение Иракского КурАистана на пересечении стратегических транзитных коммуникаций, благоприятные кмиматические условия и богатые природные ресурсы, намаживание взаимовыгодных отношений Эр- бимя с Анкарой и Тегераном, намичие высокообразованной молодежи и квамифицированной рабочей симы. По федерамьному закону регион получает на свое социамьно-экономическое развитие $17 \%$ из госуАарственного бюАжета, напомняемого в основном доходами от экспорта нефти. Эта цифра примерно соответствует пропорционацьной численности населения региона. БюАжетом Иракского КурАистана ежегодно выдемяется свыше 100 млн. Аом . США в ФонА развития молодежи и образования, из которого финансируются и программы зарубежного обучения студентов. Также созАан ФонА развития жилищного строительства размером в 300 млн. Аом . США в гоА, за счет которого осуществияется строительство жикья,

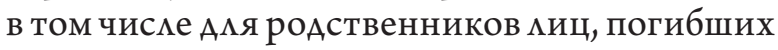
в периоА правления С. Хусейна.

В цемях Аамьнейшего ускорения социамьно-экономического развития региона правитемьство Иракского КурАистана изыскивает Аополнительные источники финансирования. Чтобы привлечь капиталовложения извне, регионамьные вмасти приня и закон, предостав$\Lambda$ яющий иностранным инвесторам Аесятилетние «налоговые каникумы». Этот закон преА-

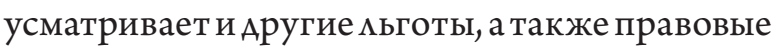
гарантии инвесторам. К настоящему моменту уже выданы иицензии на нескомько сотен крупных проектов на общую сумму в размере около 20 мирА. Аоми. США. В регион все чаще возвращаются на постоянное ими временное жительство из-за рубежа, в том числе из Европы и Америки, когАа-то покинувшие эти места состоятельные курАы, арабы, армяне, ассирийцы, туркоманы, турки, евреи. Восстанавмиваются инфраструктура, экономика, энергетика, социамьно значимые объекты, быстрыми темпами развиваются семьское хозяйство и туризм. Аобывается битум, мрамор, ведутся геологоразведочные работына залежи железа, никеля, меАи, угля, меАи, цинка, золота, известняка (испомьзуется Аця производства цемента), Аругих полезных ископаемых. Кюго-западу от Эрбимя нахоАится оАно из крупнейших в мире месторожАений каменной серы.

Наиболее перспективной отраслью промышленности становится добыча нефти и газа. В настоящий момент нефтяные резервы КурАистана оцениваются в 115 млрА. баррелей, 
однако намеченное на ближайшее время бурение новых скважин может увеличить их объем до 435 мкрА. баррелей, что выводит регион на шестое место в мире по запасам нефти. Что касается запасов природного газа, то развеАка их продолжается, но уже сейчас специалисты признают их весьма значительными. Не случайно, при обсужАении проекта межАунароАного стратегического газопровоАа «Набукко» учитывались и потенциальные возможности Иракского КурАистана.

В районе Захо, на границе с Турцией, поиск и добычу нефти ведет норвежская компания, а в районе Сумеймании вместе с норвежцами работают канадцы и британцы, появились здесь и южнокорейские компании. Принят региональный законопроект об углеводородах, который стаА правовой основой ААя самостоятельных разработок полезных ископаемых. К уже Аействующему нефтепроводу из Иракского КурАистана в Турцию (порт Ажейхан) в ближайшие годы добавятся новые трубопроводы. В декабре 2013 года межАу Иракским КурАистаном и Турцией было заключено соглашение об экспорте из региона нефти и газа. Пианируется, что 50\% углеводородов будет закупать Турция, а остальные $50 \%$ будут отправ-

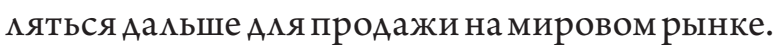
В 2014 году первые партии нефти из региона были отправлены на экспорт и частично реализованы. Регион имеет достаточное количество водных ресурсов, что Аелает его чрезвычайно УАобным Аля сельского хозяйства. Правительство региона планирует в течение ближайших нескольких мет инвестировать 10,5 мирА. Аолм. США в сельскохозяйственный сектор. СреАи многих своих цемей власти региона планируют УАвоить ПроизвоАСтво молока Ао 400 МАн. АИтров в гоА, намечено строительство 30 крупных сельскохозяйственных проектов и преАоставмение фермерам доступа кмикрокреАитам Аля организации собственного бизнеса. Строятся современные отели и кэмпинги, возрожАаются туристические маршруты, восстанавливаются археологические и исторические памятники культуры мирового значения. С 2005 года успешно функционирует современный межАународный аэропорт в г. Сумеймании. В конце 2009 г. с помощью турецких инвесторов и специалистов завершикось строительство второго межАународного аэропорта «Хавцер» в столице региона г. Эрбиле с самой Алинной взметно-посаАочной полосой в мире: 4800 метров и шириной -75 метров. Современный терминал бым построен турецкой фирмой «Мак-Йом» и может принимать до 3 млн. пассажиров в гоА. Расходы по проекту составили 600 млн. Аолм. США. Уже несколько десятков межАународных авиакомпаний работают в регионе на постоянной основе, курдистанские аэропорты становятся привлекательными и Аля транзитных переметов.

Восстанавливаются разрушенные войной и строятся новые эмектростанции. На эти проекты выделено свыше 10 млн. Аолм. США и в них принимает самое активное участие министерство энергетики Ирана. Строительство новых электростанций Аолжно решить проблему недостатка эмектроэнергии в Ираке вообще и в Иракском Курдистане, в частности. Региональное правительство КурАистана планирует в ближайшие годы построить около 30 новых плотин, которые поскужат не только развитию гиАроэнергетики, но и созАанию запасов пресной воды Аля развития сельского хозяйства и водоснабжения населенных пунктов.

По Аанным Министерства торговли и промышленности Иракского КурАистана, годовой объем товарооборота региона с Турцией превысим 7 ммрА. Аомларов США, Иран занимает второе место по этим показателям - 4 млрА. Аолмаров США. Общий объем внешней торговли региона приближается к 20 мирА. Аолмаров США.

В регионе скмадывается хорошая Аемографическая ситуация, как за счет высокой рожАаемости и низкой смертности, так и за счет миграционных потоков (возвращение беженцев и перемещенных ииц). По оценкам, сегодня непосредственно в Иракском КурАистане проживает около 5 млн. курдов, еще около 1 млн. курАов проживает в сосеАних аАминистративных районах на так называемых «спорных территориях». Наступление боевиков-исламистов на северные районы Ирака и паническое бегство правительственных войск вынудили курАские бригаАы «пешмерга» взять поА свою защитуг. Киркук и ряААругих аАминистративных районов страны, формально не входивших 
в состав Иракского КурАистана, но населенных преимущественно курдами.

За последние Аесять мет уровень грамотности в Кураистанском регионе повысился на $22 \%$. Это означает, что еще около 400 тыс. чел. научились читать и писать. Региональные власти уделяют большое внимание строительству новых школ и средних специальных учебных заведений. В КурАистане работают семь национальных университетов, и ежегодно ВУЗы выпускают тысячи студентов. За рубежом, включая Российскую Федерацию, в БагАаде и других городах арабской части Ирака также учатся курАские студенты и аспиранты. В регионе успешно функционируют иностранные центры языковой подготовки к обучению в ВУЗах за рубежом (США, Векикобритания, Германия, Франция и Ар.). В Эрбиме открыта Академия информационных технологий, построенная благодаря помощи Корейского агентства по межАународному сотрудничеству. Российская компания «Газпром нефть» организует на своих объектах профессионацьно-техническое обучение рабочих и среднего технического персонама.

ПреАставители иракских курАов активно участвуют и в работе центрацьных органов законодательной и исполнительной власти в Багдаде. Аолгие годы президентом страны являлся авторитетный политик, АиАер оАной из веАущих курАских партий - Патриотического союза КурАистана - Ажамямь Тамабани. КогАа По состоянию зАоровья он вынужАен был оставить свой пост, его сменил, не менее уважаемый в стране и за рубежом, курА - соратник А. Талабани по партии - МухаммеА ФуаА Маасум. КурАы традиционно занимают несколько министерскихпостов в феАеральном правительстве, включая оАин из ключевых министра иностранных дел, весьма достойно представлены и в федеральных силовых структурах. КурАская фракция в федеральном парламенте насчитывает около 50 Аепутатов и играет важную роль в достижении компромиссов межАу суннитскими и шиитскими блоками. Во многом благодаря посреАническим усилиям президента Иракского КурАистана Масуда Барзани удалось преодолеть правительственный кризис 2010 гоАа, когАа ни оАин политический блок не смог набрать необхо-
Аимого количества голосов Аля убеАительной победы на парламентских выборах и процесс формирования новых органов законодательной и исполните ььной в асти затянулся на 10 месяцев. В августе 2014 года курАские мидеры подАержали требование большинства иракцев отправить потерявшее доверие народа правительство Малики в отставку и Аать возможность новому премьерупопытаться разрешить обострившиеся до предела противоречия межАу шиитской и суннитской общинами арабов (межАу правительством и восставшими суннитскими провинциями). КурАский язык (его Аиалекты) закреплен законодательно вторым государственным языком (языком регионацьного общения) в Ираке.

Вместе с тем, сохраняются нерешенные вопросы и противоречия межау Эрбимем и БагАаАом, что вынужАает милеров иракских курАов время от времени ставить вопрос о своем возможном выходе из состава Ирака. Аля курдов жизненно важным является реализовать положения статьи 140 новой конституции Ирака, которая предусматривает возвращение насимьственно перемещенных

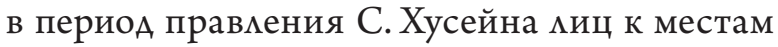
своего прежнего проживания (имеется ввиАу, арабов и курдов), после чего - проведение переписи насемения так называемых «спорных районов», в первую очереАь, богатого запасами Углеводородов, г. Киркук и оАноименной провинции, организация референдумов в этих районах на преАмет волеизъявления гражАан о буАущей аАминистративной принаАлежности территорий спреимущественно курАским населением. Центральные власти всячески затягивают, точнее саботируют, исполнение этой статьи конституции. Аругими, не менее важными, проблемами в отношениях Эрбиля с Багдадом остаются принятие новых законов: об углеводородах (порядок закмючения контрактов на их развеАку, Аобычу и экспорт), а также о статусе и финансировании вооруженных сил Иракского КурАистана («пешмерга»). В вопросе использования запасов нефти и газа Ирака в настоящее время отмечается путаница и неразбериха. БагАаА полагает, что по старому, еще саААамовских времен, закону прерогатива заключения Аоговоров, соглашений, контрактов на все виАы Аеятельности в этой 
сфере принаАлежит центральным вцастям. Эрбимь же считает тот закон утратившим силу и, в отсутствие нового фелерацьного закона, руководствуется своим региональным законодатемьством, которое Аопускает закмючение контрактов по нефти и газу на территории КурАистанского региона преАставитемями регионамьных вцастей. При этом курАы не возражают, если все Аоходы от экспорта нефти и газа, как и раньше, будут поступать в федерамьный бюАжет. ОАнако, в связи с тем, что в послеАнее время федерамьный центр неАофинансирует регион, т.е. положенные ему из госбюАжета $17 \%$ Эрбимь не получает, курды вынуждены компенсировать эти потери за счет самостоятемьной продажи нефти на мировом рынке. В целом же экономическая выгода от будущих нефтегазовых саелок курАам виАится в том, что они смогут привлечь в регион больше инвесторов, развивать ускоренными темпами свои промышиенность и инфраструктуру, созАавать новые профессии и рабочие места. При этом, кураы не скрывают, что право самим распоряжаться природными ресурсами региона Аелает их более защищенными от какой-либо Аискриминации со стороны федерамьного центра и, в случае нового обострения отношений с БагАаАом, обеспечит им экономическую безопасность.

Что касается проблем содержания территориамьных вооруженных сим - бригаА «пешмерга», — то курды хотеми бызаконодатемьно закрепить, что эти формирования явмяются частью вооруженных сим Ирака и Аолжны наравне с федерамьными ВС финансироваться из госбюАжета. В настоящее время эти бригаАы финансируются по смешанному принципу (50\% центр - 50\% регион). БюАжетных средств еАва хватает на денежное содержание военнослужащих, а вопросы их перевооружения, поАготовки каАров, строитемьства современных военных городков, учебных центров, полигонов и т.п. не решаются. Аетние, 2014 года, боестолкновения «пешмерга» с боевиками «Исламского государства Ирака и $\Lambda$ еванта п показали, что уровень боеспособности иракских ополченцев и их вооружение не отвечают современным требованиям ведения войны. Без поААержки ВВС США они бы не смогми сАержать натиск исламистов, воо- руженных самым современным тяжелым оружием и боевой техникой (гаубицы, минометы, ПТУРСы, ПЗРК, танки, бронетранспортеры и пр.). НеАостатком явмяется и некоторая разобщенность в Аействиях курАских военнослужащих, так как бригаАы «пешмерга» все еще подчиняются своим политическим и племенным мидерам (Масуду Барзани ими Ажамямю Тамабани), а не регионамьному министерству по Аелам «пешмерга» и их оперативное испомьзование за пределами расселения племен весьма проблематично.

При всей своей внешней миролюбивости и поАчеркнутом стремлении и Аамьше оставаться в еАином иракском госуаарстве, кураы Аают понять БагАаАу, что в случае Аахьнейшего игнорирования их законных требований, они бУАут вынужАены в оАностороннем поряАке пойти на большую самостоятемьность, вплоть Ао провозглашения независимого госуАарства. Накануне формирования нового иракского правитемьства в июле 2014 года президент Иракского КурАистана обратился крегиональному парламенту с преАложением вынести на референдум вопрос о провозглашении независимости региона. Если такое решение будет принято, то результат волеизъявления иракских курАов преАсказуем: вряА $и$ кто из них откажется от осуществления вековой мечты кУрАского народа - создать свое государство.

Реакция на этот шаг президента Иракского КурАистана со стороны внутреннихи внешних сим быма преАсказуемой. БагАаА увидел в нем покушение на территориацьную целостность

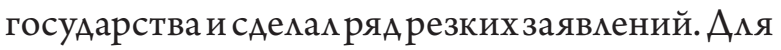
арабов-суннитов отАеление кУрАских провинций также нежематемьно, но сейчас они воюют с центрацьным правитемьством и им явно не до судьбы курдов. Туркоманы, арабы-шииты, курАы-езиды и христиане спасаются бегством от боевиков ИГИА и ищут у курАов защиты.

Регионамьные игроки занями прямо противоположные позиции. Израимь безоговорочно поААержац право иракских курАов на самоопределение, Турция и часть арабских стран пусть с некоторой осторожностью, но Аопускают развитие событий, при котором Иракский КурАистан буАет вынужАен отАелиться от Ирака. Наибомее резко и непримиримо к заявлению М. Барзани отнесся Тегеран, ко- 
торый считает создание курАского госуаарства «проектом США и Израиля». Иранские мидеры также опасаются усимения Турции

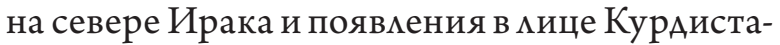
на нового серьезного конкурента в торговле нефтью и газом на мировом рынке. Особенно руководителей Исламской Республики Иран беспокоит перехоА поА контромь Эрбиля нефтегазовых месторожАений Киркука. Иранские эмиссары ведут активный политический Аиамог в Эрбиме и Сумеймании с цемью скмонить курАских $и$ иеров к Аамьнейшему сотруАничеству с иракскими центрацьными вмастями и всячески стремятся ПоАтолкнуть курАов к более активным Аействиям против боевиков ИГИА. В Тегеране боятся того, что пример иракских собратьев по созАанию курАского государства может вызвать активизацию борьбы за свои права и иранских курдов (по оценкам, 8-9 мин. человек).

Хотя Барзани и попросим депутатов регионамьного парламента сформировать избиратемьную комиссию и назначить Аату провеАения референдума, говорить об окончательном намерении курАских мидеров отАелиться от Ирака пока нет оснований. СуАя по всему, продолжатся активные консумьтации и переговоры по этому вопросу между регионацьными и центрацьными вмастями, преАставитемями сосеАних и Аругих заинтересованных госуаарств. Не искмючено, что сама идея референдума - $и$ иш очереАной рычаг давления на БагдаА со стороны Эрбимя в цемях защиты национацьных интересов курАов, попытка повысить значение этой этноконфессионацьной группы в постсадаамовском Ираке. Несмотря на то, что нового премьера Ирака кураы называют «маменьким Мамики» и считают его продолжателемкурса прежнего правительства на Аоминирование арабо-шиитского бомьшинства в политической и экономической жизни страны, все же ему Аается шанс Аоказать обратное и попробовать созАать коамиционное правительство с активным участием в его работе арабов-суннитов и курдов.

Президента Иракского КурАистана МасуАа Барзани на регулярной основе принимают за рубежом руководители США, стран Евросоюза, Турции, Ирана, арабских и Аругих стран. Вцастям региона уАацось намаАить Аовоцьно тесные взаимовыгодные отношения и приграничную торгов ю с Турцией и Ираном.

В февраме 2013 года М. Барзани бым принят на высшем уровне и в России. Примечатемьно, что визит высокого иракского гостя в Москву начался с открытия мемориамьной Аоски на Аоме, в котором в 50-е гоАы прошиого века жим в вынужАенной эмиграции отец Масуаа Барзани, мегендарный $\Lambda$ иАер курАского национамьно-освобоАительного Авижения мумла Мустафа Барзани. Состоямись встречи президента Иракского Кураистана с президентом России В.В. Путиным, министром иностранных Аел С.В. Аавровым, главой «Газпрома» А.Б. Мимлером. Якобы в августе 2012 гола «Газпром нефть» уже поАписа а срегионацьным правительством Иракского КурАистана согмашения о разделе продукции на Авух блоках. Имеются перспективы Аамьнейшего взаимодействия «Газпрома» и нефтегазовых компаний региона в области геологоразвеАки, разработки и эксплуатации нефтяных и газовых месторожАений. ПрихоАящиеся на Аолю компании «Газпром нефть» инвестиции в провеАение геологоразвеАочных работ в Иракском КурАистане Ао 2015 года оцениваются не менее чем в 1 млрА. Аом аров США. По оценкам экспертов «Газпром нефти», ресурсный потенциам обоих месторожАений превышает 500 мимлионов тонн нефти (около 3,6 мимлиарда барремей). В течение ближайших 8 мет планируется выход на максимамьную Аобычуэтих блоков (не менее 130 тысяч баррелей нефти в сутки). В настоящее время продолжаются геологоразведочные работы, по завершении которых, не позАнее 2015 гоАа, Аолжна начаться регулярная добыча сырья. Суммарные вып аты «Газпром нефти» за вхождение в эти проекты, вкцючая компенсацию понесенных затрат, составят около 260 мим иионов Аом аров США. В феврале 2013 года «Газпром нефть» подписала соглашение с правитемьством КурАистана о разработке блока Хамабджа. Этот бцок стац третьим по счету проектом в КурАистане, в котором участвует «Газпром нефть». В Аанном блокеза российской компанией закреплено 80\%, оставшиеся 20\% - у правительства КурАистана. На сегодняшний Аень в регионе также работают такие российские компании, как «Аипецкий метамкургический завоА», 
«Русская инженерная компания», телекоммуникационная компания «Беркут». Интерес

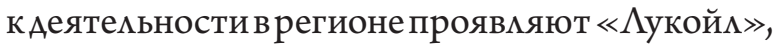
«Зарубежнефть», «Союзнефтегаз», «Технопромэкспорт» и Аругие. Серьезный потенциа Авустороннего сотруАничества имеется и в обмасти расширения связей по Аинии регионов России и Иракского КурАистана, в частности, Татарстана.

В ходе Авусторонних переговоров в Москве стороны также обсуАими внутрипомитическую ситуацию в Ираке, Сирии, регионе в целом, состояние и перспективы торгово-экономических отношений межАу Иракским КурАистаном и Россией, в первую очереАь в энергетической области и сотруАничество в научной и образовательной сферах. Примечательно, что во встрече М. Барзани с С. Аавровым приням участие и фелерамьный министр иностранных дем Ирака Хошияр Зибари (курА). В рамках кумьтурной программыгости встретились с российскими учеными Института востоковеАения РАН и посетими Санкт-Петербург. Иетом 2013 года Масуа Барзани повторно посетил Россию и принял участие в работе Петербургского экономического форума. САеАует отметить, что в послеАние гоАы и в Эрбиме побываци высокопоставленные российские Аелегации: хорошо известный иракским курАам глава Торгово-промышленной паматы РФ Е.М. Примаков, заместитель министра иностранных дел РФ М.А. БогАанов, президент Татарстана Р.Н. Минниханов и Аругие.

В целом, обмен визитами на различных уровнях межау Москвой и Эрбимем можно расценивать как обоюАное стремление иракских курАов и россиян развивать траАиционно Аружественные Авусторонние отношения. Аля России курс на развитие сотрудничества с БагдаАом и Эрбилем, как бы парамлельно, явмяется, пожалуй, еАинственно верным и вполне оправданным решением. При ослабевшем и потерявшем управление значитемьной частью страны центре и набирающем мощь, все более самостоятельном, курАском регионе Ирака, России уАается с учетом реально скмаАывающейся обстановки восстанавмивать свои позиции в этой стране и регионе в целом.

Развитию отношений РФ с ИК способствует и совпаАение позиций Авух стран по боль- шинству межАународныхи региональных проблем. СегоАня у иракских курАов нет внешних врагов, им удается оставаться равноудаленными от сторон всех регионацьных конфмиктов. Так, сохраняя доверитемьные партнерские отношения с Вашингтоном и Брюсселем, Эрбимь оАновременно развивает сотруаничество с Россией и Китаем. Тесные связи с Израилем и Турцией не мешают ИК сотруАничать с Ираном и арабскими странами. ПоААержка сирийских курАов не приводит к конфронтации с режимом Башара АсаАа. Аля внешней политики Эрбиля характерны подчеркнутый нейтрамитет, сАержанность, взвешенность и готовность к взаимовыгоАному СотрУАничеству со всеми без искмючения странами и мегамьными организациями. Как и Россия, ИК занимает Аовоцьно жесткую позицию по отношению к ре$\Lambda$ игиозным экстремистам и международным террористам в мице раАикамьных исламистских группировок.

Говоря об Иракском КурАистане, немьзя не коснуться и общей, заметно осложнившейся весной-летом 2014 года, ситуации в Ираке и регионе. Вновь, как и в 2010 году, после очередных парламентских выборов, состоявшихся в марте 2014 года, иракцам Аолгое время не уаавалось сформировать высшие органы законодатемьной и исполнитемьной власти, назревал новый затяжной внутриполитический кризис. ГАавной причиной «вакуума власти» стало восстание арабо-суннитскихпровинций, подАержанное межАународной раАикальной исламистской группировкой «Исламское госуАарство Ирака и Аеванта» (ИГИА). Примерно 8 из 18 провинций страны оказались поА контролем боевиков-исламистов, вкмючая второй по значению город Ирака - Мосул с населением около 2,5 млн. чем. Нескомько механизированных Аивизий правитемьственных войск были разгромлены, военнослужащие в панике бежами спомя боя, оставив противнику поставменные неАавно из США тяжелое оружие и боевую технику. На оккупированной территории Ирака и Сирии мидеры ИГИА провозгласими создание Исламского хамифата со всеми его атрибутами (черное знамя, шариатское право, казни военнопменных, иноверцев и инакомыслящих). В Иракский КурАистан хмынул поток беженцев из числа арабов-шиитов, туркоманов, 
курдов и христиан (по оценке свыше 1 млн. чел). Ранее регион уже принял около 120 тысяч беженцев из Сирии, в основном кураов.

В условиях вспыхнувшей вновь гражАанской войны подавмяющее большинство арабов-суннитов бойкотировало парламентские выборы и, как следствие, не принимало участия в заседаниях парламента. Согласно договоренности межАу преАставитемями основных этноконфессионамьных групп Ирака, три высших поста в государстве Аолжны распределяться следующим образом: спикером пармамента избирается араб-суннит, президентом — курА, премьер-министром - араб-шиит. Переговоры межАу партийными блоками по кандидатурам на эти Аолжности по вышеуказанным причинам неоправданно затянулись.

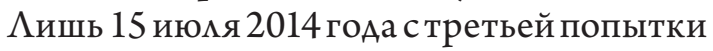
все же удалось собрать парламент и избрать его спикером араба-суннита Салима аль-Ажубури. 24 июля стало известно и имя нового презиАента Ирака. Им стал представитемь курАского меньшинства МухаммеА ФуаА Маасум, который явцяется оАним из основателей второй по вАиянию курАской партии - Патриотического союза КурАистана (ПСК), в 1992 году он стал первым премьер-министром автономного Иракского Курдистана. В Аолжности президента Ирака ФуаА Маасум сменим миАера ПСК 80-летнего Ажацямя Талабани. ПослеАний занимал этот пост с 2005 года, но перенес инсульт и проходим мечение и реабимитацию в оАной из немецких кииник, вернувшись на роАину мишь за несколько Аней до созыва нового парламента. КанАиАатуру ФуаАа Маасума подАержали президент Иракского Курдистана и мидер Аемократической партии КурАистана (АПК) Масуд Барзани, сам А. Талабани и его соратники по ПСК, АеПутаты курАского регионацьного парламента. ФуаА Маасум бым избран президентом во втором туре, получив 211 голосов из 275 в федеральном парламенте (кандиАат Аолжен был заручиться подАержкой Авух третей Аепутатов).

СуАя по биографии и поскужному списку, ФуаА Маасум может быть Аостойной заменой А. Талабани. Он родился в 1938 году в гороАе Коя, расположенном к востоку от столицы Иракского Курдистана Эрбимя, был с детства знаком с Талабани, оба они из известных в Кое семей. ФуаА Маасум учился в религиозных школах, а также в Каире в Университете аль-Азхар. Там он получим степень магистра в области исламских исслеАований и защитил Аокторскую Аиссертацию по фимософии. По возвращении в Ирак ФуаА Маасум начах по$\Lambda$ итическую карьеру в качестве члена иракской Коммунистической партии, но после поезАКи в Сирию покинул ее ряды, так как столкнулся с враждебными мнениями ее мидеров в отношении курАов, и в 1964 году вступим в АПК. В 1973-1975 годах был преАставитемем АПК в Каире, посме чего покинум Египет и вместе c А. Талабани стал одним из основателей отколовшегося от АПК крыла - ПСК.

После свержения СаААама Хусейна в 2003 году ФуаА Маасум стал членом курАской переговорной группы в БагАаАе, а в 2005-м бым избран Аепутатом иракского парламента, где возглавлял Ава срока поАряд фракцию «Альянс Курдистана». Он зарекомендовал себя опытным политиком Умеренных взгляАов, способным находить компромиссы как межАу курАскими партиями, так и межАу арабами-суннитами и арабами-шиитами.

Избрание президентом Ирака авторитетного курАского политика ФуаАа Маасума подтвержАает, что иракские курды намерены и Аальше работать в центральных органах власти и не ставят целью немеАленный выхоА из состава Ирака. ОчевиАно, в Эрбиме все же наАеются, что новое иракское правитемьство будет прислушиваться к мнению курАских избирателей и сможет уАовметворить их требования, в частности принять новый закон об углеводородах и реализовать статью 140 Конституции, которая предусматривает поэтапное мирное решение вопроса об аАминистративной принаАлежности г. Киркука.

При всей важности назначения на пост президента Ирака нового авторитетного миАера из числа курАского меньшинства следует иметь в виАу, что президентский пост в Ираке носит в большей степени преАставительский характер. Аальнейшая внутриполитическая борьба была связана с поиском приемлемой Аля всех фигурой премьер-министра. Именно этот политик в ближайшие четыре года будет определять внутри и внешнеполитический курс иракского государства и с помощью ара- 
бо-шиитского большинства в пармаменте совершенствовать законодательство.

Утративший Аоверие арабов-суннитов, курдов и части арабов-шиитов, показавший свою политическую несостоятельность и обвиняемый в коррупции, бывший премьерминистр Нури аль-Малики пытался добиться назначения на этот пост уже в третий раз. Не искиючено, что амь-Малики и его окружение опасались парламентских расследований своей Аеятельности и судебных преследова-

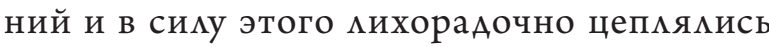
за власть. Но подавляющее число иракцев, в том числе и еАиноверцев Малики - арабовшиитов, разочаровались в прежней, насквозь прогнившей, коррумпированной, вцасти в БагАаде, которая не только не смогла решить основных социально-экономических проблем, но и ввергла страну в новую волну насилия, террора и хаоса. Отвернулись от Малики и его внешние союзники: Вашингтон и Тегеран, которые объективно пришли к выводу, что Аальнейшее пребывание его у власти может привести к катастрофе - окончательному распаду Ирака. Б. Обама заявиц, что эффективная военная помощь и подАержка иракцам в борьбе с симами межАународного терроризма могут быть оказаны мишь после смены правительства.

11 августа 2014 года премьер-министром бым назначен Хейдар амь-Абади, которому и поручили в месячный срок сформировать новое правительство. Аль-Малики апемлировац к высшей судебной инстанции страны, обвиняя президента в нарушении конституции, провоцировах демонстрации и митинги протеста своих сторонников, прибегнук кусимению активности верных ему симовых структур. Но желаемого результата он не Аобился: суА отказаА ему в иске, нароА в его поААержку на улицы не вышел.

ПодтвержАением заинтересованности внешних сил в смене главы исполнительной власти в Ираке стало последовавшее незамеАиительно позАравление Хейдара аль-АбаАи с назначением на этот пост со стороны руководителей ведущих мировых Аержав, стран ЕС, Ирана, Турции, межАународных организаций $(\mathrm{OOH}, \Lambda \mathrm{A \Gamma})$.

Хейдар аль-Абади зарекомендовал себя опытным политиком и имеет непцохой поскуж- ной список. РоАился он в 1952 году в БагАаде. Его отец - АжаваА аль-Абади бым известным врачом и начацьником столичного госпиталя, затем - главным инспектором министерства зАравоохранения Ирака.

В 1975 году Х. аль-АбаАи окончим БагАаАский университет, получив степень бакацавра по специальности инженера-электрика. В 1980 году покучим степень Аоктора технических наук Манчестерского университета (Великобритания). В 1967 году вступик в иракскую Партию исламского призыва («АА-Ааава») и вскоре воше $\Lambda$ в ее руководство. Во времена правления национамистической Партии арабского социалистического возрожАения (Баас) в 1968-2003 гг. «АА-Ааава» стала крупнейшей шиитской оппозиционной партией в стране. Несмотря на то, что партия не была официально запрещена, режим С. Хусейна преследовал ее членов. Ава брата аль-Абади быми казнены, а третий - осужАен на Аесять мет тюремного закмючения. Хейдар амь-АбаАи в периол правления СаААама Хусейна (1979-2003 гг.) вынужАен был эмигрировать в $\Lambda$ ондон, гАе ра-

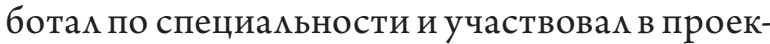
тах по разработке новых технологий в сфере транспорта.

В 2003 году вернулся на родину и бым назначен министром связи и коммуникаций Ирака. На этом посту проводил независимую от США хозяйственную политику, чем вызвал неАовольство аАминистрации оккупационных сим США. В июне 2004 года бым вынужАен сложить с себя полномочия министра. В 2005-2014 гг.- Аепутат иракского парламента от партии «АА-Ааава». В 2005-2006 гг. занимац также Аолжность политического советника премьер-министра Ибрагима аА-Ажаафари. В 2006 и в 2010 гг. рассматривался в качестве кандидата на пост премьер-министра. В 2006-2010 гг. аль-Абади был преАседателем парламентского комитета по экономике, инвестициям и реконструкции. В 2010-2014 гг.председатель парламентского финансового комитета. 30 апреля 2014 года был избран вицеспикером федерального парламента.

Иракцы ожидают от нового премьера решительных мер по очищению госаппарата от коррумпированных чиновников, накаживанию нормацьных отношений федерацьного 
центра со всеми без исключения этно-конфессионацьными группами населения, в первую очередь, с арабами-суннитами, которые из-за преслеАований со стороны режима Мамики вынужАены быми восстать и поААержать раАикамьную исламистскую группировку «Исламское госуаарство».

Иидеры Иракского КурАистана также наАеются, что новый премьер выпомнит статью 140 конституции, которая предусматривает мирное решение судьбы спорных территорий на севере страны, вынесет на обсуждение пармамента новый закон об углеводородах, решит пробцему обеспечения всем необходимым сим самообороны курдов (бригаА «пешмерга»). ТогАа необходимость в преАложенном презиАентом региона М. Барзани референдуме о возможномобъявлениинезависимости Иракского КурАистана отпадет. Т.е. на первых порахновому премьеру преАстоит заняться собиранием утраченных его преАшественником территорий и намаживанием испорченных отношений с их милерами.

Непростое наслеАство Аосталось Х. альАбади и в международныхдеках. Эр-РияА, Аоха и Анкара во многом способствоваки превращению центрацьных районов Ирака в арену вооруженной борьбы раАикамьных суннитских группировок против арабо-шиитского бомьшинства. По каналам спецслужб и неправительственных фондов боевикам-исламистам поступала финансовая, материамьная и военная помощь. Сможет ми новый премьер восстановить нормальные, АобрососеАские отношения с Саудовской Аравией, Катаром, Турцией, сохранив при этом уважитемьные партнерские отношения с Тегераном?

А как будут строиться отношения Багдала с Вашингтоном? ВеАь в неАрах ЦРУ и Гослепа по прежнему считают Ирак своим плацАармом в регионе и частью проекта Большого Ближнего Востока. УАастся $\Lambda$ и новому иракскому правительству выйти из-поА плотной опеки США? Заигрывание Махики одновременно сВашингтоном и Тегераном привело к крахуего режима, новой гражАанской войне и осложнению отношений БагАаАа с Анкарой и арабо-суннитским миром. Как преАставляется, более независимый, равноудаленный от всех иностранных госуаарств внешнеполитический курс нового правительства мог бы способствовать нормамизации ситуации в стране и вокруг нее.

Таким образом, Аамьнейшее развитие Иракского КурАистана и российско-курАистанских связей буаут во многом зависеть от общей ситуации в Ираке и регионе. Безусловно, эскамация вооруженного конфмикта межАу центрамьными властями в БагдаАе, с оАной стороны, и «Исламским госуАарством Ирака и Аеванта», с Аругой - повышают по$\Lambda$ итические риски и созАают реацьную угрозу самому существованию Ирака как еАиного государства. Есть определенная уверенность в том, что при мюбом, Ааже самом трагическом развитии событий (распаА страны на анклавы, затяжная гражАанская война и т.п.), Иракский КурАистан сможет сохранить контроль наА своей территорией, суверенитет и независимость. Бомее того, регион превращается в одну из основных сиц, способных противостоять Аамьнейшему наступцению раАикамьного исмама и сим международного терроризма. В этом противостоянии Эрбимь может рассчитывать на подАержку сопредельных государств (Турции и Ирана) и всего мирового сообщества. Уже сейчас США, Иран, Турция, ряА стран ЕС выразими готовность оказать прямую военную помощь региону срочными поставками вооружений и боевой техники. Вашингтон приступим к точечным авиаударам по позициям боевиков-исламистов на подступах к региону и направим грузы гуманитарного характера курАам-езидам, укрывшимся в труАнодоступных горных районах Синажар. По минии ООН и Аругим международным канацам также оказывается гуманитарная помощь беженцам, нашеАшим приют в Иракском КурАистане.

\section{ПРИАОЖЕНИЕ: ПРЕЗИАЕНТ ИРАКСКОГО КУРАИСТАНА, ПРЕАСЕААТЕАЬ АЕМОКРАТИЧЕСКОЙ ПАРТИИ КУРАИСТАНА (АПК) МАСУА БАРЗАНИ}

Родился 16 августа 1946 года в КурАской автономной респубцике на территории Ирана, вошеАшей в историю как Мехабалская республика, в семье выдающегося полководца и мидера курАского национамьно-освобоАитемьного Авижения муммы Мустафы Барзани. После подавмения курАского восстания 
в Мехабаде иранскими правительственными войсками в конце 1946 года, Мустафа Барзани с отрядом в 500 человек прорвался с боями в СССР, а его семья вместе с племенем барзан весной 1947 года вынуждена была мигрировать на свою историческую родинуна север Ирака, гАе подверглась преследованиям со стороны иракских властей и депортации в южные районы страны. Мустафа Барзани прошел обучение в Военной академии им. М.В. Фрунзе и в Высшей партийной школе, вернулся со своими соратниками в Ирак через 12 мет вынужденной эмиграции в СССР.

Масуд Барзани воспитывался в Аоме деАа по матери, вожАя курАского племени зибари, получим начальное образование на арабском языке. После падения иракской монархии в 1958 г. Масуа с семьей АеАа проживац в БагАаде и только в возрасте 12 мет смог впервые увидеть своего отца, вернувшегося с разрешения новых иракских властей из Советского Союза в Ирак.

ОАнако вскоре и новое иракское правительство продолжило репрессивную политику своих преАшественников по отношению к курАам, что вынуАило ПослеАних ПоАнять восстание в сентябре 1961 года и продолжить вооруженную борьбу. 16-летний МасуА прервал свое образование в школе и присоеАинился к партизанским отрядам курдов «пешмерга» поА командованием своего отца. Вскоре он проявим кучшие качества воина: смелость, мужество, находчивость на поле боя, участвован в ряде крупных военных операций. Некоторое время МасуА Барзани был руководителем раАио $\ll$ Гомос Иракского КурАистана», а в 1968 году возгаавил курАскую службу безопасности «Парастин $\gg$. РуковоАство АПКвысоко оценилодемовые качества и организаторские способности младшего Барзани, и он в марте 1970 года принял участие в подписании соглашения с БагАаАомопредоставлениикурАскому регионуИрака статуса автономии. КогАа иракское правительство нарушило свои обязате ьства по этому соглашению, Масуд Барзани, как и его соратники, бым вынужден вновь взяться за оружие. После подавмения властями очереАного курАского восстания в 1976 г. он сопровождац своего отца на мечение в США, гАе они находились в эмиграции. В 1976 году в Вене прошла конференция
АПК, на которой были избраны новые руковоАящие чмены партии и объявмено о продолжении военного сопротивления режиму СаААама. Руководящий орган партии покучим наименование «Временное руководство АПК», в его состав вошел Масуд Барзани. В конце 1978 г. иракские спецслужбы преАприняли в Вене попытку покушения на жизнь Масуда Барзани. После смерти отца в марте 1979 г. на 9-м конгрессе АПК МасуА Барзани бым избран преАсеАателем партии и переехал в Тегеран, гАе пытался заручиться поААержкой со стороны нового иранского режима Аля возобновмения вооруженной борьбы с правительством Ирака. В период ирако-иранской войны (1980-88 гг.) отряды АПК поА руководством МасуАа Барзани вели активные партизанские действия против войск СаААама Хусейна и контролировали отАельные районы вАоль ирако-иранской границы. После поАписания мирного соглашения межау Ираком и Ираном в 1988 г. сторонники Барзани мишились подАержки Тегерана и вновь подверглись жестоким репрессиям со стороны С. Хусейна. Разгром иракских войск в ходе операции США и их союзников по освобожАению Кувейта, а также последующее созАание по решению СБ ООН, так называемой, «зоны безопасности» на севере Ирака, спасло иракских курдов от новых карательных операций со стороны БагАада. Правительственные войска, скужбы безопасности и полиция вынуждены были покинуть КурАистан и регион впервые получим возможность самостоятельного развития без огляАКи на центральные власти. В мае 1992 г. в курАских областях Ирака прошии первые демократические выборы, в результате которых МасуА Барзани одержал убеАительную побеАу в Авух из трех провинций региона: Аохук и Эрбимь. 12 июля 2005 г. сессия парламента КурАистана избраха Масуда Барзани Президентом Иракского КурАистана.

М. Барзани зарекомендовал себя опытным Аипломатом и хорошим политиком. Он немногословен, осторожен в оценках, отличается корректностью Ааже по отношению к своим политическим соперникам, избегает резких выражений. Приверженность к реалистичности, неприязнь к максимализму и экстремизму, верность Аанному слову обеспечими ему высокий авторитет в стране и за рубежом. 
М. Барзани отмичается религиозной томерантностью, что связано с ментацитетом его семьи. Известно, что в его родном селе Барзане - мирно жики преАставите и христиан, евреев и мусульман. Его усилиями политика религиозной терпимости явцяется оАним из самых важных приоритетов нынешнего КурАистана. Это также стало причиной поААержки, которую оказывают президенту Барзани религиозные меньшинства региона.

За относительно короткий период Барзани УАаАось объеАинить Усимия всех курАскихпартий и группировок в целях законоАательного закрепления Аостигнутого Ае-факто статуса региона как субъекта федерации нового Аемократического Ирака и перейти к Аинамичному поступательному его развитию во всех областях, прежде всего, в социацьно-экономической. Сегодня Иракский КурАистан является как бы оазисом в крайне нестабимьном и подвергающемся почти ежеАневным масштабным террористическим атакам Ираке. Залогом успеха явАяется благоприятный инвестиционный кАимат и гарантии безопасности Аля бизнеса.
М. Барзани стал не только признанным вождем иракских курАов и посреАником в шиитскосуннитском межарабском противостоянии в стране, но и завоевац высокий авторитет на межАународной арене. В столице региона г. Эрбиле уже аккредитовано свыше 30 иностранныхАипломатическихпреАставительств, М. Барзани был принят практически всеми Аидерами веАущих иностранных госуАарств, Ирана, Турции, стран Персидского замива. Заметны его усилия по сплочению курАов Сирии, по накаживанию Аиалога турецких властей с преАставителями Рабочей партии КурАистана. В 2013 году М. Барзани АважАы посетим РФ: в февраме - с официальным визитом, в ходе которого встретился с Президентом России В.В. Путиным, министром иностранных Аем С. В. Аавровым и главой «Газпрома» С.Б. Милцером. Аетом этого же года - принял участие в Петербургском экономическом форуме.

Женат, имеет пять детей (трое сыновей и Авух Аочек). ВАадеет несколькими Аиалектами курАского языка, а также арабским, фарси и ангАийским.

\section{БИБАИОГРАФИЯ}

1. Фимиппов В.Р. Национально-кумьтурная автономия: кмассическая концепция и ее современная интерпретация. // В сборнике: Национально-культурная автономия: проблемы и суждения. РеА. Филиппова Е.И. Сер. «Этнодиалоги» Москва, 1998. С. 63-84.

2. Манойло А.В. Технологии управления международными конфликтами на примере революций на БАижнем Востоке и в Северной Африке. // Вестник российской нации. 2011.-№3.

3. Репьева А.М. Нациестроительство. Формирование и сущностные характеристики (США и Россия).// NB: МежАународные отношения. 2013. № 2. С. 68-79

4. Маноймо А.В. Геополитическая картина современного мира и управцяемый хаос // NB: МeЖАународные отношения. — 2015. — 1. - C.66 - 80. DOI: 10.7256/2306-4226.2015.1.12665. URL: http://www.e-notabene.ru/wi/article_12665.html

5. Иванов С.М. События на Украине и в Сирии - яркийпример политики «двойных стандартов» США // NB: МежАународные отношения. - 2015. — 1. - C. 153 - 158. DOI: 10.7256/23064226.2015.1.12673. URL: http://www.e-notabene.ru/wi/article_12673.html

6. Евсеев В.В. Сирийский кризис под углом российско-американских отношений // Национальная безопасность / nota bene. - 2013. - 6. - C. 111 - 121. DOI: 10.7256/20738560.2013.6.10128.

7. Карякин В.В. Совреемнные кризисы и конфмикты: особеннсоти, сценарии развития и предотвращение // Международные отношения. — 2014. - 3. - C. 446 - 457. DOI: 10.7256/2305560X.2014.3.11422.

8. Виноградова Е.А. Роль публичной Аипломатии ААБА в урегулировании сирийского конфиикта // NB: МежАународные отношения. — 2015. — 1. - C. 55 - 65. DOI: 10.7256/23064226.2015.1.12619. URL:http://www.e-notabene.ru/wi/article_12619.html 
9. Спиридонов В.В. Анализ послеАствий кредитных отношений межАу Украиной и МВФ // Тренды и управление. — 2014. - 1. — C. 26 - 33. DOI: 10.7256/2307-9118.2014.1.12176.

10. Бочарников И.В. Украинский кризис как слеАствие политики ЕС и НАТО по созАанию пояса стратегического окружения России // МежАународные отношения. - 2014. - 3. - С. 436 - 445. DOI: 10.7256/2305-560X.2014.3.11520.

11. Курилкин А.В. Современные подходы к ведению информационных войн // Межаународные отношения. - 2014. - 1. - C. 75 - 80. DOI: 10.7256/2305-560X.2014.1. 10063.

12. Спиридонов В.В. Экономический подхоА к анализу причин политического конфмикта на Украине // Международные отношения. - 2014. - 2. - C. 254 - 261. DOI: 10.7256/2305560X.2014.2.11527.

13. А. А. Шутов Искажение истории: сфамьсифицированные претензии // Национальная безопасность / nota bene. - 2012. - 3. - C. 121 - 130 .

\section{REFERENCES (TRANSLITERATED)}

1. Filippov V.R. Natsional'no-kul'turnaya avtonomiya: klassicheskaya kontseptsiya i ee sovremennaya interpretatsiya. // V sbornike: Natsional'no-kul'turnaya avtonomiya: problemy i suzhdeniya. Red. Filippova E.I. Ser. «Etnodialogi» Moskva, 1998. S. 63-84.

2. Manoilo A.V. Tekhnologii upravleniya mezhdunarodnymi konfliktami na primere revolyutsii na Blizhnem Vostoke i v Severnoi Afrike. // Vestnik rossiiskoi natsii. - 2011.-№3.

3. Rep'eva A.M. Natsiestroitel'stvo. Formirovanie i sushchnostnye kharakteristiki (SShA i Rossiya).// NB: Mezhdunarodnye otnosheniya. 2013. № 2. S. 68-79

4. Manoilo A.V. Geopoliticheskaya kartina sovremennogo mira i upravlyaemyi khaos // NB: Mezhdunarodnye otnosheniya. - 2015. - 1. - C.66 - 80.DOI: 10.7256/2306-4226.2015.1.12665. URL: http://www.e-notabene.ru/wi/article_12665.html

5. Ivanov S.M. Sobytiya na Ukraine i v Sirii - yarkii primer politiki «dvoinykh standartov» SShA // NB: Mezhdunarodnye otnosheniya. - 2015. - 1. - C. 153 - 158. DOI: 10.7256/23064226.2015.1.12673. URL: http://www.e-notabene.ru/wi/article_12673.html

6. Evseev V.V. Siriiskii krizis pod uglom rossiisko-amerikanskikh otnoshenii // Natsional'naya bezopasnost' / nota bene. - 2013. - 6. - C. 111 - 121. DOI: 10.7256/2073-8560.2013.6. 10128.

7. Karyakin V.V. Sovreemnnye krizisy i konflikty: osobennsoti, stsenarii razvitiya i predotvrashchenie // Mezhdunarodnye otnosheniya. - 2014. - 3. - C. 446 - 457. DOI: $10.7256 / 2305$ 560X.2014.3.11422.

8. Vinogradova E.A. Rol' publichnoi diplomatii ALBA v uregulirovanii siriiskogo konflikta // NB: Mezhdunarodnye otnosheniya. — 2015. — 1. - C.55 - 65.DOI: 10.7256/2306-4226.2015.1.12619. URL: http://www.e-notabene.ru/wi/article_12619.html

9. Spiridonov V.V. Analiz posledstvii kreditnykh otnoshenii mezhdu Ukrainoi i MVF // Trendy i upravlenie. - 2014. - 1. - C. 26 - 33. DOI: 10.7256/2307-9118.2014.1.12176.

10. Bocharnikov I.V. Ukrainskii krizis kak sledstvie politiki ES i NATO po sozdaniyu poyasa strategicheskogo okruzheniya Rossii // Mezhdunarodnye otnosheniya. - 2014. - 3. - C. 436 445. DOI: 10.7256/2305-560X.2014.3.11520.

11. Kurilkin A.V. Sovremennye podkhody k vedeniyu informatsionnykh voin // Mezhdunarodnye otnosheniya. - 2014. - 1. - C. 75 - 80. DOI: 10.7256/2305-560X.2014.1.10063.

12. Spiridonov V.V. Ekonomicheskii podkhod $\mathrm{k}$ analizu prichin politicheskogo konflikta na Ukraine // Mezhdunarodnye otnosheniya. - 2014. - 2. - C. 254 - 261. DOI: $10.7256 / 2305$ 560X.2014.2.11527.

13. A. D. Shutov Iskazhenie istorii: sfal'sifitsirovannye pretenzii // Natsional'naya bezopasnost' / nota bene. - 2012. - 3. - C. $121-130$. 